\title{
NOTES ON THE PUFFBALL BEETLE, CAENOCARA OCULATA (SAY)
}

By Harry B. Weiss, New Brunswick, N. J.

This member of the family Anobiidae was described by Say in 1824 (App. vol. II, Keating's Exp. to source of St. Peters Riv. under Maj. Long, Phila., 1824, p. 273) and has long been known to collectors as being associated with the fungi commonly called puffballs. Blatchley (Col. Ind., 1910, p. 884) records it from Indiana as occurring throughout the state on low vegetation in damp localities and also in small puffballs (Lycoperdon). Smith (Ins. N. J., p. 307) records it as common throughout the state but does not mention any host.

For the past two years it has been noted at Monmouth Junction, N. J., breeding in a species of puffball known as Scleroderma vulgare and undoubtedly occurs in many localities where its host grows. Leng (Check List Col. Amer. N. of Mex. p. 244) indicates its wide distribution by the following localitiesCt., Fla., New Eng., Ariz., Ind.

Fungi belonging to the genus Lycoperdon are small puffballs with somewhat thickened bases or stalks. When young the interior is soft, white and firm; later it becomes yellowish and finally forms a purplish brown, dusty mass consisting of spores and threadlike filaments. Species of this genus appear in the summer and autumn and are common on the ground or on old stumps, usually in clusters. In the genus Scleroderma, the plants are sessile or nearly so. The peridium is thick and leathery and sometimes becomes cracked and ruptured at the apex. Scleroderma vulgare in which Conocara oculata was found breeding is about $5 \mathrm{~cm}$., in diameter, subglobular, with a thick, yellowish or pale brown scaly or warty, leathery peridium. The spore mass is purplish black. This species is quite common and occurs in dry places and on hard ground. At Monmouth Junction, N. J., the fructifications were found in the dry parts of a large wooded area. 
On September 5, several adults of Canocara oculata were noted with their bodies projecting slightly from small circular holes in the walls of the fungi. Upon cutting such fungi open, they were found to contain, in addition to the blackish, powdery mass of spores, numerous full grown larvæ some of which had constructed pupal chambers or cells. One puffball contained fully 100 larvæ. Many of the larvæ pupated by September 9 and on September 22 fully colored adults were found in the cells.

When full grown each larva constructs an oval cell in the spore mass. These are about $4 \mathrm{~mm}$., long and $2 \mathrm{~mm}$., wide and many are attached to the inner side of the peridial wall. Pupation takes place in these cells and when the adult is ready to emerge it simply eats through the wall of the fungus. Upon examining these exit holes it will be found that they are shallow and extend in only to the depth of the pupal cell. The larvæ undoubtedly do most if not all of their feeding in the fungus when it is young as at this time, the interior is solid and fleshy. When ripe, the spore mass is dry and powdery.

Larvo. Length about $4 \mathrm{~mm}$. Width about $1.5 \mathrm{~mm}$. Form subcylindrical, tapering toward head, posterior end rounded, somewhat white grub-like in appearance. Body curved, almost semicircular in outline. White except for brownish mouth parts. Head small, subcircular, bearing minute hairs; collum absent; antennæ single jointed, minute, almost obsolete; ocelli absent; cranial sutures indistinct; gula membraneous; ventral mouth parts fleshy. Clypeus and labrum distinct, former transverse, latter small, semicircular bearing several minute hairs on anterior edge. Mandibles comparatively large, heavy, broad across base, narrowing toward tip which is strongly bifid. Lacinia and galea distinct, well separated, each bearing chitinous hairs; maxillary palpi two-jointed, second joint tapering and twice as long as the first; labium with mentum and submentum indistinct; labial palpi two-jointed. Body segmentation indistinct; body bearing numerous minute hairs and irregular transverse rows of larger hairs on raised dorsal folds of thoracic and ab- 
dominal segments. Anal end of body and anal area bearing numerous longer hairs. True legs absent, indicated by ambulatory tubercles.

Pupa. Length about $3 \mathrm{~mm}$. Width about $1.8 \mathrm{~mm}$. White; oval; posterior end of abdomen terminated by a pair of tubercles each bearing a short, weak spine; remainder of body surface devoid of spines or hairs.

Adult. Reference to the place of original description has already been made and Blatchley's description (Col. Ind. p. 884) is available if the original is not. The adult is interesting on account of its ability to pack itself up into a little globe or ball. The legs shut together; a cavity on the breast receives the antennæ and large mouth parts and the head is folded down over the chest closing this cavity. In such a closely packed condition, the insect resembles a small seed. When disturbed, it immediately folds up. 

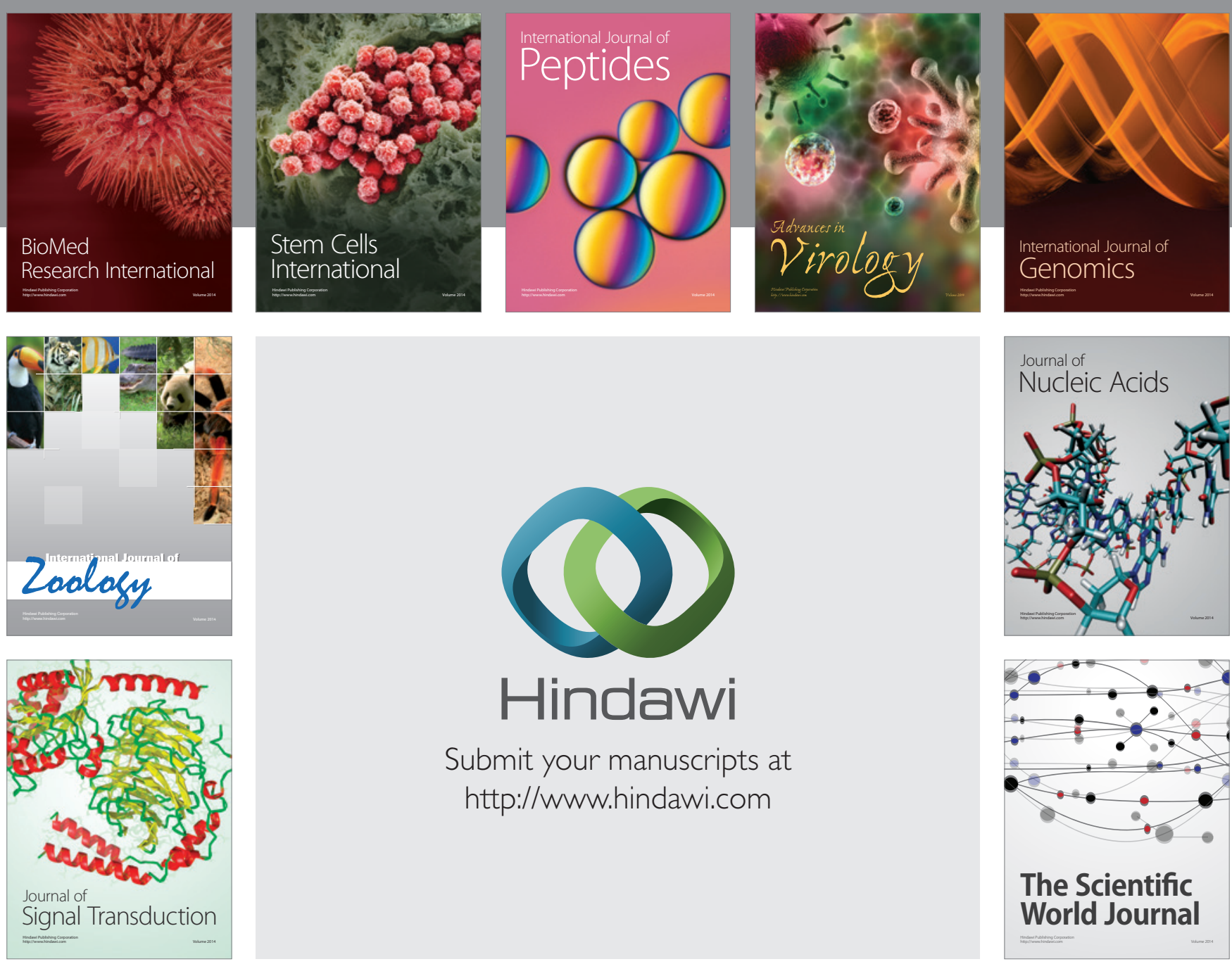

Submit your manuscripts at

http://www.hindawi.com
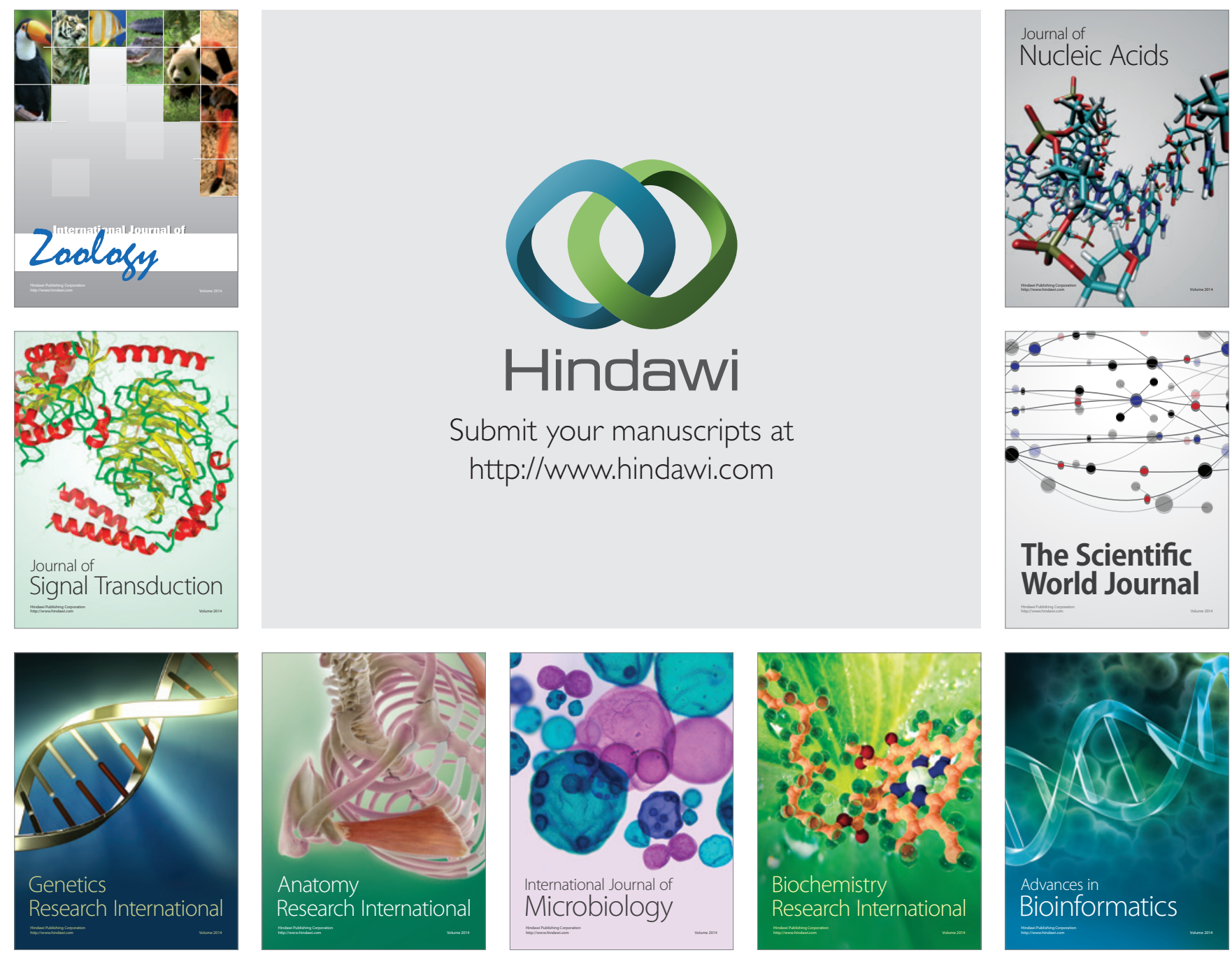

The Scientific World Journal
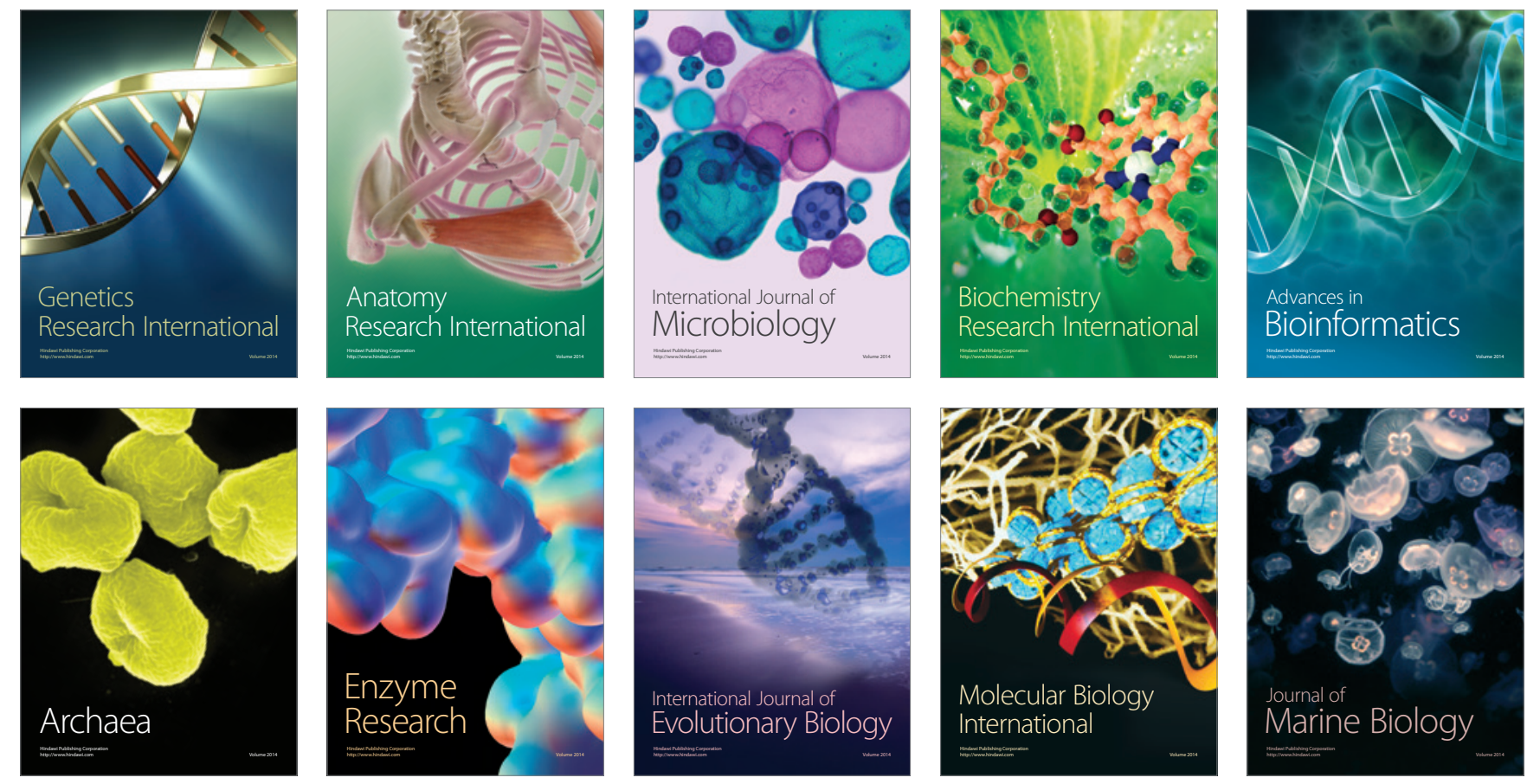